\title{
How Much of the Diversification Discount Can be Explained by Poor Corporate Governance?*
}

\author{
Daniel Hoechle ${ }^{\mathrm{a}}$, Markus Schmid ${ }^{\mathrm{b}, \#}$, Ingo Walter ${ }^{\mathrm{c}}$, and David Yermack ${ }^{\mathrm{c}}$ \\ ${ }^{a}$ Department of Finance, University of Basel, $\mathrm{CH}-4051$ Basel, Switzerland and \\ Man Investments, Pfaeffikon, $\mathrm{CH}-8808$, Switzerland \\ ${ }^{b}$ Swiss Institute of Banking and Finance, University of St. Gallen, \\ CH-9000 St. Gallen, Switzerland \\ ${ }^{c}$ Department of Finance, Stern School of Business, New York University, \\ New York, NY 10012, USA
}

This version: September 15, 2009

\begin{abstract}
We investigate whether the diversification discount is simply a proxy for poor corporate governance. We find that the negative value impact of diversification is amplified by adverse governance variables such as low CEO ownership, low board independence, and board classification, and that approximately $25 \%$ to $30 \%$ of the diversification discount can be attributed to suboptimal governance choices by conglomerate firms. Our methodology includes a dynamic panel GMM estimator that accounts for the endogeneity of the diversification decision and corporate governance, plus an event study analysis of diversifying mergers. Even after controlling for governance, the diversification discount remains negative and significant.
\end{abstract}

Keywords: Organizational structure; Diversification; Firm valuation; Corporate governance JEL Classification: G32, G34

\footnotetext{
* We are grateful to Yakov Amihud, Gayle DeLong, and Urs Peyer for helpful comments and Hae Jin Chung for research assistance. All errors are our own. Part of this research was completed while Yermack was a visiting professor at Erasmus University Rotterdam.

${ }^{\#}$ Corresponding author: Tel.: +41-71-224-70-31; fax: +41-71-224-70-88. E-mail: markus.schmid@unisg.ch. Address: Swiss Institute of Banking and Finance, University of St. Gallen, Rosenbergstrasse 52, CH-9000 St. Gallen, Switzerland.
} 


\section{How Much of the Diversification Discount Can be Explained by Poor Corporate Governance?}

\section{Introduction}

A large body of corporate finance research over the past 15 years has documented the low valuation of diversified companies relative to their apparent breakup values. ${ }^{1}$ To date, no consensus explanation has emerged for this pattern, although authors have proposed and tested many hypotheses. Lamont (1997) and Ozbas and Scharfstein (2008) provide evidence of inefficient investment patterns, under which conglomerate firms operate an internal capital market that transfers cash flows between divisions, causing some businesses to be underfunded and others to be over-funded relative to the outcomes that would occur if each business raised capital externally. Baker (1992) indicates that the administrative cost associated with an internal capital market may create a significant drag upon the firm value, regardless of whether capital is allocated effectively. Graham, Lemmon and Wolf (2002) point to inefficient patterns of diversifying takeovers, showing that firms tend to acquire lowquality assets when buying firms in another industry. Other explanations suggested by academics and industry observers include the poor transparency of accounting data produced by conglomerates (e.g., Bushman, Engel, and Smith, 2004), the inability to use equity incentive compensation efficiently when contracting with divisional managers in a diversified firm, and the alienation of shareholder clienteles that would prefer to invest in single-industry firms.

\footnotetext{
${ }^{1}$ Lang and Stulz (1994) and Berger and Ofek (1995) are the first major papers. Recently Laeven and Levine (2007) report a sizeable diversification discount for an international sample of banks between 1998-2002. Schmid and Walter (2009) find a similar discount for U.S. financial intermediaries between 1985-2004. Ammann, Hoechle, and Schmid (2009) report a robust and significant discount of between 5\% and 21\% for U.S. non-financial firms between 1998-2005.
} 
Other papers argue that the diversification discount may be illusory. An influential literature begun by Mansi and Reeb (2002) notes that most measures of firms' enterprise values rely upon their book values of debt as an input to the calculation, but diversified firms' debt may trade at a premium to book value as a result of the risk-reducing effects of diversification. $^{2}$ Campa and Kedia (2002) and Villalonga (2004a) argue that the diversification discount may be endogenous, as it represents the outcome of inferior investment choices deliberately made by poor managers who may seek the security of large firm size or the human capital insurance effect of diversification. Villalonga (2004b) shows that estimates of the discount rely upon the ad hoc industry segment reporting choices made by individual firms, and that the discount may disappear if different industry definitions are used in place of those chosen by listed companies.

This paper investigates a further possible explanation for the diversification discount: poor corporate governance. Beginning at least as early as Amihud and Lev (1981), many papers have conjectured that the diversification discount arises from agency problems such as empire building, managerial hubris, and executives' pursuit of insurance to protect their human capital value (see, e.g., Houston, James, and Ryngaert, 2001; Aggarwal and Samwick, 2003; and Laeven and Levine, 2007). This reasoning is supported by the empirical findings of Denis, Denis, and Sarin (1997), who show that firms with higher managerial shareholdings are significantly less likely to be diversified, that diversification is negatively related to the equity ownership of large outside blockholders, and that decreases in diversification occur due to external corporate control threats, financial distress, and management turnover. Lins and Servaes (2002) find the diversification discount in their sample - including companies from seven Asian emerging markets - to be driven by firms with managerial ownership in the $10 \%$ to $30 \%$ range, where they expect managerial entrenchment to be highest. They also find the

\footnotetext{
${ }^{2}$ Glaser and Mueller (2009) and Grass (2009), studying German and U.S. samples, respectively, show that by using market values instead of book values of debt the conglomerate discount is somewhat reduced but remains significant.
} 
diversification discount to be most severe when the insiders’ voting rights exceed their cash flow rights by $25 \%$ or more. These findings are confirmed by Fauver, Houston, and Naranjo (2003). Taken together, these studies suggest that agency problems are at least partly responsible for firms’ value-reducing diversification strategies.

We construct a panel dataset with a large range of corporate governance variables and explore how much of the discounted value of diversified firms appears to arise from the structure of their corporate governance. We take a more comprehensive view of governance than prior studies in the area, which have focused almost exclusively on ownership variables to measure potential agency problems. ${ }^{3}$ Along with CEO and institutional ownership, our analysis considers the effects of board size, board independence, board classification, nominating committee independence, the percentage of directors who joined the board before the current CEO took office, a "powerful CEO” dummy variable, and the Gompers, Ishii, and Metrick (2003) index of takeover defenses.

Endogeneity represents a crucial issue in investigating both of corporate diversification and the structure of corporate governance. Campa and Kedia (2002) and Villalonga (2004a), for example, show that diversification strategies are determined endogenously and that failing to account for this endogeneity may lead to erroneous detection of a diversification discount. Similarly, research into the valuation effects of corporate governance has shown that firmlevel governance variables arise endogenously (e.g., Agarwal and Knoeber, 1996; Coles, Lemmon, and Meschke, 2006; Larcker, Richardson, and Tuna, 2007). We attempt to account for both the endogeneity of the corporate diversification decision and the endogeneity of corporate governance attributes. We do this in three ways. First, we include firm and year fixed effects in our standard regression specifications to mitigate potential omitted variables

\footnotetext{
${ }^{3}$ The only exception we are aware of is Anderson, Bates, Bizjak, and Lemmon (2000), who examine the relation between corporate diversification and several corporate governance mechanisms including the sensitivity of CEO compensation to performance, shareholdings of officers and directors, outside blockholdings, the sensitivity of CEO turnover to performance, and the board composition. However, that paper's sample size is limited to 199 firms and it does not address the potential endogeneity of the corporate governance variables as well as the diversification decision.
} 
bias. Second, we estimate a dynamic panel GMM estimator as proposed by Wintoki, Linck, and Netter (2008). This approach relaxes the assumption that all the unobserved heterogeneity that leads to the correlation between the corporate governance variables and the error term is constant over time. Additionally, it alleviates the problem of slowly moving corporate governance indices over time which may render fixed effects techniques ineffective (e.g., Coles, Lemmon, and Meschke, 2006). Third, we circumvent the potential problems associated with panel regressions by performing an event study analysis of all diversifying mergers undertaken by our sample firms. We regress the cumulative abnormal returns obtained in this event study against our corporate governance variables to investigate whether the announcement effects depend upon firm-level corporate governance.

To estimate how much of the diversification discount can be attributed to corporate governance, we regress our measure of firm value against a dummy variable for diversified firms and a range of control variables, with the estimated coefficient on the diversification dummy serving as a baseline estimate of the discount. We then reestimate the same regression with governance variables included, and in every case we find that the estimated diversification discount becomes less negative, moving toward zero. Our estimates from six different regression models indicate that between $12 \%$ and $41 \%$ of the diversification discount can be explained by the governance structure of conglomerate firms; the mean across the six models is $25.9 \%$ or about one-fourth of the discount. Although the estimated diversification discount is reduced by the presence of governance controls, it nevertheless remains statistically and economically significant. Consequently we conclude that the diversification discount is partly, but not completely, a proxy for poor corporate governance. Consistent with these findings, results from the event study suggest that better corporate governance is associated with less value destruction (or more value creation) when diversifying mergers occur. 
The remainder of the paper is organized as follows. Section 2 describes the construction of variables, the dataset, and sample selection criteria. Section 3 presents the main results obtained from fixed effects panel regressions and a dynamic panel GMM estimator. Section 4 contains the results from the event study analysis of diversifying mergers. Section 5 concludes.

\section{Sample description}

Our sample consists of all firms with data reported on both the Compustat Industrial Annual and Segment data files, and it covers the period from 1992-2005. The sample period in prior studies of the diversification discount usually ends in 1997 or earlier, ${ }^{4}$ likely because in 1997 the SIC classification system was replaced by NAICS, and after 1997 segment information conforms to a different reporting standard (SFAS 131 instead of FASB 14). ${ }^{5}$ Because of this change, segment data before and after 1997 may not be directly comparable, and our data does exhibit a structural break in the percentage of diversified sample firms, which jumps from approximately 20\% in 1997 to 30\% in 1998 while being relatively stable before and after. Therefore, we perform a number of robustness checks as described below, and we include year dummy variables in all our regressions to pick up the effect of possible changes in segment reporting over time.

Following Berger and Ofek (1995) and others, we exclude years in which at least one segment is classified as being in the financial sector (SIC 6000-6999; NAICS 520000529999) and firm-years with total sales of less than \$20 million. We also exclude ADRs.

\footnotetext{
${ }^{4}$ To the best of our knowledge, there are only two studies of the diversification discount in non-financial U.S. firms using post-1997 data: Mansi and Reeb (2002) and Ammann, Hoechle, and Schmid (2009).

${ }^{5}$ We rely exclusively on NAICS codes for industry classification as they are available from 1990 to 2005 and therefore cover the whole sample period, while SIC codes are available until 2000 only. Using SIC instead of NAICS (where available) does not change any of our results. It is important to note that the number of segments and all segment information is identical irrespective of whether SIC or NAICS is used. SIC codes after 1997 and NAICS codes before 1998 are simply a translation of the NAICS (SIC) codes reported at the time.
} 
To examine whether diversification increases or decreases corporate value, we use the excess value measure developed by Berger and Ofek (1995). This measure compares a firm's value to its imputed value if its segments were operated as stand-alone entities. The imputed value for each segment is calculated by multiplying the segment's sales (or assets) by the median ratio of market value to sales (or to assets) for single-segment firms in the same industry. Our industry median ratios are based on the narrowest NAICS grouping that includes at least five single-segment firms with complete data and total sales of at least \$20 million. ${ }^{6}$ The imputed value of the firm is then calculated as the sum of its imputed segment values. The excess value measure is calculated as the log of the ratio of a firm's actual value (market value of equity plus book value of debt) over its imputed value.

Some of the segments of diversified firms in our sample have no NAICS codes assigned by Compustat. However, most of them have a segment name, usually stated as "corporate and other," "eliminations,” “corporate and unallocated,” or a similar designation. We do not treat these segments separately and attribute their sales (assets) proportionally to the remaining segments in order to sum to the correct figure for the firm's total sales (assets). Nevertheless, for some firms the sum of all segment sales (assets) as provided by the Compustat Segment file disagrees with the respective firm total values from the Compustat Industrial Annual file. This problem is also noted by Berger and Ofek (1995), and we follow their approach by excluding observations for which the sum of the segment values deviates from the firm's total value by more than 5\%. If the deviation is within 5\%, we gross the firm's imputed value up or down by the percentage deviation between the sum of its segments' sales (assets) and total firm sales (assets). Finally, again following Berger and Ofek (1995), we exclude extreme excess values from the analysis, dropping those that depart from the actual value in either direction by a factor of four or more.

\footnotetext{
${ }^{6}$ Using sales multipliers, the imputed value for $68.1 \%$ of all segments are based on six-digit NAICS codes, $9.0 \%$ on five-digit NAICS codes, $12.5 \%$ on four-digit NAICS codes, $9.4 \%$ on three-digit NAICS, and $1.0 \%$ on twodigit NAICS codes. The figures for assets multipliers are very similar.
} 
These screens lead to a final sample size of 7,218 firms with a total of 37,740 firm-year observations for the sales-based excess value measure, and 6,998 firms with a total of 34,557 firm-year observations for the asset-based excess value measure. Including lagged control variables and particularly the corporate governance variables, substantially reduces the sample size in our multivariate analyses to between 2,427 and 6,959 firm-year observations.

Finally, we construct a third alternative excess value measure which is based on both sales and assets. The underlying presumption behind this hybrid measure is that in some industries asset multiples are more meaningful, while in other industries sales multiples may be more meaningful. We assume that a lower standard deviation of the multipliers of focused firms in an industry implies a higher precision in measurement and therefore a more meaningful imputed segment value. Therefore, we calculate imputed values for each firm segment based on both sales and asset multiples, and we choose the one for which the industry standard deviation is lowest. ${ }^{7}$

We use nine different governance attributes to measure a firm's corporate governance structure. We obtain CEO ownership from Standard \& Poor’s Execucomp database and institutional shareholdings from Thomson Financial's CDA/Spectrum. ${ }^{8}$ Board size, board independence (the percentage of outside directors), a dummy variable for an independent nominating committee, and the fraction of the board that predates the appointment of the CEO are all obtained from the Investor Responsibility Research Center's (IRRC) Directors database. A dummy variable for classified boards and the count variable for takeover defenses used in

\footnotetext{
${ }^{7}$ We are grateful to Yakov Amihud for suggesting this approach.

${ }^{8}$ Alternatively, we use the percentage of shares owned by outside blockholders (excluding officers, directors, employee ownership plans, and other affiliates of the company) compiled by Dlugosz, Fahlenbrach, Gompers, and Metrick (2006). However, the inclusion of this variable substantially reduces the number of observations. In contrast to our significant results for the institutional shareholdings variable, the coefficient on the outside blockholdings variable is usually insignificant but leaves the other results qualitatively unchanged.
} 
Gompers, Ishii and Metrick (2003) are extracted from the IRRC Governance database. ${ }^{9}$

Finally, we follow Adams, Almeida, and Ferreira (2005) and construct a "powerful CEO” dummy variable that equals 1 when the CEO is the only insider on the board and also serves as chairman and president. ${ }^{10}$

Table 1 reports descriptive statistics for the subsamples of diversified and focused firms, with all companies reporting more than one business segment classified as diversified. Most notably, the three excess value measures and Tobin's Q are all significantly higher for focused than for diversified firms, providing prima facie evidence of a diversification discount. Other financial data indicate that diversified firms are substantially larger, have higher leverage, higher operating profit margins, lower R\&D expenditures scaled by sales, and lower historical sales growth compared to focused firms.

Further data in Table 1 give mixed indications of whether diversified firms exhibit better or worse corporate governance than focused firms. Diversified firms exhibit lower CEO ownership, lower outside blockholdings, larger board size, a lower incidence of independent nominating committees, a higher incidence of "powerful” CEOs, a higher Gompers, Ishii, and Metrick (2003) governance index (indicating more takeover defenses), and a higher incidence of classified boards compared to focused firms. All of these variables suggest that diversified firms have inferior governance structures. However, data indicate that diversified companies also tend to have higher institutional investor ownership, more independent outside directors, and a higher percentage of directors who joined the board

\footnotetext{
${ }^{9}$ Because IRRC Governance data is not available for each year, we follow Gompers, Ishii, and Metrick (2003) and assume that the firms' governance attributes as reported in a given IRRC series remain unchanged until publication of the subsequent series. Alternative filling methods leave our results qualitatively unchanged.

${ }^{10}$ We try several other specifications of this variable and obtain qualitatively identical results in the regressions below.
} 
before the current CEO took office, all indications of superior governance compared to focused firms. ${ }^{11}$

\section{Empirical Results}

\subsection{Regression analysis of the diversification discount}

In this section, we test for the existence of a diversification discount during our sample period from 1992 to 2005. Throughout the whole section, we estimate panel regressions with firm and year fixed effects and Driscoll and Kraay (1998) standard errors, which are heteroskedasticity-consistent and robust to general forms of cross-sectional and temporal dependence. ${ }^{12}$ We include firm and year fixed effects to mitigate potential omitted-variables bias and to control for the effect of unobserved variables that are constant over time as well as unobserved variables that are constant over firms. To refute the underlying presumption that the unobserved heteroskedasticity that leads to correlation between the potentially endogenous variable(s) and the error term is constant over time, we estimate two alternative specifications which allow the firm fixed effects to be time-varying. Specifically, we include separate firm fixed effects for two alternative market regimes and thereby allow the firm fixed effects to vary between these two different market environments. In the first specification, we differentiate between years with positive and years with negative stock market returns, as measured by the S\&P 500 composite index. Second, we include firm fixed effects that differ between boom and recession periods, as measured by a GDP growth above or below the time series median.

\footnotetext{
${ }^{11}$ It is important to keep in mind that these results are univariate. As diversified firms are about 2.5 times larger than focused firms, limited wealth of the CEO and outside blockholders might be responsible for their lower ownership in diversified firms.

${ }^{12}$ Driscoll and Kraay (1998) show that erroneously ignoring cross-sectional dependence in the estimation of linear panel models can lead to severely biased statistical inference. In the context of this study, cross-sectional correlation may arise when the decision to diversify or to implement a specific corporate governance provision of one particular firm is related to or coincides with the decisions of other firms. Alternatively, we also estimate the panel regressions with cluster-robust standard errors and firm and year fixed-effects and find the results to remain qualitatively unchanged.
} 
We base the choice of our control variables on prior research (e.g., Berger and Ofek, 1995) and include the natural log of total assets, the ratio of capital expenditures to sales, and the ratio of operating profits (EBIT) over sales in our standard regression specification. In addition, we include historical growth in sales over the prior three years to control for growth opportunities (e.g., see Yermack, 1996). We also include leverage (total debt over total assets), as it might affect firm value based on the role of debt in helping to discourage managers’ overinvestment of free cash flow.

The left three columns of Table 2 report the regression estimates obtained by using the three alternative excess value measures for the complete sample period 1992-2005. Columns 4 to 6 report results for the 1992 -1997 period, when segment reporting was based on FASB 14, and columns 7 to 9 show estimates for the 1998-2005 period when segment reporting was based on SFAS 131. Irrespective of the choice of the excess value measure and the sample period, results in Table 2 show that the estimated diversification discount is similar to that reported in prior research (e.g., Berger and Ofek, 1995; Servaes, 1996, Lins and Servaes, 1999; and Ammann, Hoechle, and Schmid, 2009), with all coefficients negative and significant below the $1 \%$ level and individual coefficient estimates implying a discount between $5.8 \%$ and $12.7 \%$ across the sample.

Because many papers studying the diversification discount have raised issues of variable measurement and methodology, we replicate our analysis using a number of alternative approaches in order to verify that our estimate of a diversification discount is robust. In various models which are untabulated to save space, we use a Heckman sample selection model as done in Campa and Kedia (2002), we redefine our excess value measure using the market value of debt estimated based on the Merton (1974) model, and we exclude all firm-years observations in which a firm makes a major acquisition or has made one within the prior five years. None of these adjustments, whether alone or in combination with the 
others, has much impact on our estimate of the diversification discount, as we continue to estimate it in a range between $9 \%$ and $12 \%$.

\subsection{The diversification discount and corporate governance}

Analysis in this section investigates whether value losses associated with corporate diversification really occur because of poor corporate governance. If badly governed firms have a tendency to diversify, perhaps through acquisitions or misguided investment programs, then the diversification discount may be a mere symptom of a larger problem.

We begin by including our corporate governance variables in our excess value regressions. If the diversification discount arises because of poor corporate governance, we would expect the coefficient on the diversification dummy variable to turn insignificant once the appropriate corporate governance variables are included in the regression.

Column 1 of Table 3 shows estimates for a fixed effects regression in which the dependent variable equals the excess value measure using multiples based on sales. The main explanatory variable is the indicator for diversified firms with two or more business segments. All models in Table 3 also include the full range of explanatory variables included in Table 2. In line with prior research, we estimate a diversification discount of 9.3\% using this approach, as indicated by the negative and significant estimate on the diversification dummy variable.

We explore the importance of corporate governance by augmenting our regression model with eight corporate governance variables and retaining all of the other explanatory variables. Results appear in the second column of Table $3 .^{13}$ We continue to find a negative and significant estimate for the diversification variable, but it drops from -0.093 to -0.081 , a reduction of about $13 \%$, once the governance variables are included. A similar pattern occurs

\footnotetext{
${ }^{13}$ Our sample size of 711 firms and 2,427 observations in Table 3 is considerably reduced from the sample sizes reported in Table 2. The loss of observations occurs due to inclusion of the governance variables. To allow for straightforward comparisons between the regression results with and without the governance variables, every regression model in Table 3 uses the identical set of observations.
} 
in the middle two columns and right two columns of Table 3, in which we repeat the analysis using different measures of the dependent variable. In the second column, inclusion of the governance variables reduces the diversification variable’s estimate from -0.081 to -0.069 , a drop of about $15 \%$, and in the right column the estimate falls from -0.063 to -0.051 , a reduction of about $19 \%$. The difference between the coefficients on the diversification dummy variables in the third and fourth columns is significant at the $10 \%$ level and between the fifth and sixth columns at the 5\% level, respectively. In contrast, the reduction in the conglomerate discount between the first and second columns is insignificant. ${ }^{14}$

Elsewhere in Table 3, most of the governance variables enter the regressions with the expected sign and are statistically significant. Consistent with prior literature (e.g., Habib and Ljungqvist, 2005), we estimate a positive effect of CEO ownership on excess firm value. In line with McConnell and Servaes (1990) and Kole (1995), among others, the squared term of CEO ownership has a negative and significant estimate, indicating a curvilinear relationship between CEO ownership and excess firm value. The coefficient on institutional shareholdings is positive and significant. Similarly, McConnell and Servaes (1990) find a positive relationship between institutional ownership and Tobin's $Q$. The estimate for the log of board size indicates a negative and borderline significant relation between board size and firm value. The coefficient on the dummy variable for independent nominating committee is negative and significant in one model, a somewhat counter-intuitive result that nevertheless is consistent with Brick and Chidambaran (2007), who find that an independent nominating committee is negatively related to future firm performance. Finally, the estimate for the classified board dummy variable is negative and significant in one model, confirming the results in Faleye (2007) that classified boards help to entrench the management and thereby

\footnotetext{
${ }^{14}$ To test for the significance of the difference between the coefficients on the diversification dummy variables, we perform a seemingly unrelated estimation of the two models to combine the estimation results. Thereby, the parameter estimates and associated (co)variance matrices are stored into a single parameter vector and simultaneous (co)variance matrix. We then apply a simple test for equality of the coefficients in the two models.
} 
destroy firm value. The coefficients on all other corporate governance variables are insignificant.

Overall, the results in Table 3 indicate that some, but not all, of the diversification discount may be due to the governance structures of diversified firms. We explore this possibility further in analysis shown in Table 4, in which we estimate regressions including interaction terms between the diversification dummy variable and the different corporate governance variables. This approach seeks evidence for whether the valuation effects of certain governance choices become especially severe in diversified firms.

The left column of Table 4 reproduces the results from the second column of Table 3 , which serves as a benchmark for this analysis. In the right column, we include eight more variables, representing the product of the diversification dummy variable and each of the eight governance variables. Results shown in the right column indicate that a number of these interaction terms have significant estimates. The positive and (borderline) significant coefficient on the interaction term between diversification and CEO ownership indicates that a higher CEO ownership is associated with a significant reduction in the diversification discount. The coefficient on the interaction term between board size and diversification is positive, larger in magnitude than the coefficient on board size, and borderline significant indicating that in diversified firms board size is positively related to firm value. This result is consistent with Coles, Daniel, and Naveen (2008) who show that board size is positively related to firm value in more complex (i.e., larger, diversified, and high-debt) firms. The results further indicate a positive and significant coefficient on the interaction term between diversification and the percentage of independent outsiders on the board. This result indicates that a larger number of independent outsiders on the board creates value in diversified firms (the positive coefficient on the interaction term is larger in absolute terms than the negative coefficient on the percentage of independent outsiders on the board) while reducing firm value in focused firms. Consistent with Gompers, Ishii, and Metrick (2003), the coefficient on their 
corporate governance index related to takeover defenses and shareholder rights is negative and significant at the $1 \%$ level (a lower index value indicates better shareholder protection). The interaction term between the index and diversification, however, is positive and significant indicating that a higher index (i.e., poorer shareholder protection and stronger antitakeover defense mechanisms) are associated with a higher firm value in diversified firms. We find this estimate somewhat puzzling, because conglomerate firms that are more vulnerable to takeover should be more attractive candidates for value-increasing bustup acquisitions. Finally, we find the estimate for the classified board dummy variable to be insignificant, while its interaction term with the diversification dummy variable is negative and significant. This result suggests that the (weak) negative relation between firm value and a classified board documented in Table 3 is mainly associated with diversified firms (see Faleye, 2007).

In separate estimations that are untabulated to save space, we repeat the analysis in Table 4 with different specifications of fixed effects, allowing them to differ between years with positive and years with negative returns of the S\&P 500 composite index and also between economic growth and recession periods. The results remain qualitatively unchanged.

\subsection{Principal components analysis of corporate governance}

The large number of corporate governance variables in our regressions may cause our analysis of diversification and governance to become unwieldy. Therefore, we follow Larcker, Richardson, and Tuna (2007) and apply principal component analysis to condense the information contained in the governance parameters. Those authors argue that principal component indices have considerably less measurement error than any individual governance variable. We use an oblique rotation that allows the principal components to be correlated in order to enhance the interpretability of the results, and we omit the variable measuring the fraction of the board whose tenure predates the CEO's appointment. Unlike our other 
measures, that variable is never significant in our analysis when used individually, and it introduces missing values that reduce our sample size. We retain the first three principal components, which jointly explain $58.2 \%$ of total variance in the original governance characteristics. To interpret the principal components, we use a similar approach to Larcker, Richardson, and Tuna (2007) and associate with each component those governance characteristics that have a factor loading in excess of 0.40 in absolute value. Factor loadings are reported in Table 5, Panel A.

Instead of directly using the principal components as governance indices, we follow Larcker, Richardson, and Tuna (2007) and construct governance indices (“construct scores”) by calculating equal weighted averages of the standardized versions of those governance characteristics that exhibit factor loadings in excess of 0.40 in absolute value. Since these alternative governance indices are weighted averages of standardized variables, their mean equals 0 and variance equals 1 . Each principal component is then assigned a name based on the governance characteristics that exhibit a factor loading in excess of 0.40 in absolute value. Table 5, Panel B reports these names, the expected sign of the association between each principal component and firm value, and the percentage of variance explained by each component individually as well as cumulatively.

As robustness checks, we use two alternative approaches to constructing the principal components. In one approach, we follow the procedure above but include the variable for the fraction of directors predating the CEO. In the other approach, we directly use the principal components as governance indices instead of using the equally weighted averages of the standardized versions of the governance attributes with factor loadings in excess of 0.40 in absolute value. Results of our analysis are qualitatively unchanged using either of these variables.

Table 6 presents regression analysis in the same format as Table 3, but with the three principal components used in place of the eight governance variables. Under this approach, 
we again see the diversification discount's estimate become closer to zero (less negative), as it falls from -0.093 without the governance controls to -0.067 , a reduction of about $28 \%$, once the controls are included. The difference between the two estimates of the conglomerate discount is significant at the $1 \%$ level. However, the discount's estimate continues to retain its significance either with or without the governance controls.

As indicated in Table 5 we expect a negative correlation between firm value and the first of these governance indices, and a positive correlation between value and both the second and third governance indices. The first two estimates follow this pattern, having the expected sign and statistical significance, but the third estimate does not, as it is negative and significant instead of positive. This negative estimate is most likely due to the dummy variable for independent nominating committee, which exhibits a negative and significant coefficient in column 2 of Table 3. As discussed below, the unexpected negative estimate for the third principal component does not retain its significance in similar models with slightly different specifications.

In columns 3 to 6 of Table 6 , we repeat the analyses reported in columns 1 and 2 while allowing the firm fixed effects to be time-varying. In columns 3 and 4 , the fixed effects are allowed to differ between years with positive and years with negative returns of the S\&P 500 index. In columns 5 and 6, the firm fixed effects differ between boom and recessionary periods, based upon whether the year's GDP growth is above or below the time series median growth. In general, the results remain qualitatively unchanged in these alternative specifications with a few exceptions, the most important being that the diversification dummy variable further decreases somewhat in magnitude but remains significant in all specifications. The estimated discount falls from -0.081 to -0.048 , a drop of about $41 \%$, in the middle two columns, and it falls from -0.063 to -0.038 , a drop of about $40 \%$, in the right two columns. The reduction in the discount resulting from the inclusion of the three governance indices is significant at the $1 \%$ level in both cases. 


\subsection{The problem of endogeneity}

In this section, we address the potential endogeneity of diversification, firm value, and corporate governance by estimating a dynamic panel GMM model. Recent papers argue that such endogenous relations may be dynamic (e.g., Wintoki et al., 2008). For example, Hermalin and Weisbach (2004) and Wintoki et al. (2008) argue that current actions of a firm affect future corporate governance as well as performance, which will in turn affect the firms' future actions.

To control for such a dynamic endogeneity, unobservable heterogeneity, and simultaneity, we follow Wintoki et al. (2008) and use the dynamic panel GMM estimator as proposed by Arellano and Bover (1995) and Blundell and Bond (1998). The estimation consists of three steps: First, we rewrite the regression equation as a dynamic model that includes lagged performance (with one and two lags) as an explanatory variable. Second, we first difference all variables. This controls for unobserved heterogeneity and eliminates a potential omitted variables bias. Third, we estimate the model by GMM and use lagged values of the governance variables, diversification variable, and performance as instruments. Using lagged variables as instruments for the present values of these variables controls for potential simultaneity and reverse causality. In addition, this estimation procedure allows all the explanatory variables (i.e., the governance variables and all control variables) to be treated as endogenous. We only treat the year dummy variables as exogenous variables. ${ }^{15}$

The results of a specification including only the diversification dummy and control variables are reported in column 1 of Table 7 . As compared to the first column of Table 3 the discount is somewhat higher when the dynamic endogeneity, unobservable heterogeneity, and simultaneity are accounted for based on the dynamic GMM estimator. The specification in column 2 additionally includes the individual governance variables. In general, the results are qualitatively similar when compared to column 2 of Table 3, whereas the coefficients on the

\footnotetext{
${ }^{15}$ Many papers in the literature use instrumental variables approaches. However, these are problematic because of a lack of suitable instruments for corporate governance (e.g., Larcker et al., 2007).
} 
dummy variable for an independent nominating committee dummy and a dummy variable for a classified board are insignificant here. Most importantly, the estimate of the conglomerate discount decreases to $8 \%$ - a decrease of roughly $29 \%$ as compared to column 1 . In column 3 , we replace the nine individual governance variables by the three PCA-based indices. The results indicate a decrease in the discount of $38 \%$ as compared to column 1 to an insignificant $7 \%$.

Summarizing, the results in this section substantiate our finding of a substantial decrease in the conglomerate discount when the effect of governance is accounted for by controlling for dynamic endogeneity, unobservable heterogeneity, and simultaneity in a dynamic GMM framework. Hence, the results in this section alleviate endogeneity concerns and provide evidence of a causal link between diversification, corporate governance, and firm value.

\section{Event study of diversifying mergers}

In this section we study the stock market reactions to all diversifying mergers undertaken by our sample firms. To investigate the effect of corporate governance on diversification, we regress the cumulative abnormal returns from the event study on our corporate governance attributes and indices.

We identify diversifying mergers by isolating all firm-years that show an increase in the number of segments in the Compustat Segement database. We then extract from Thomson Financial's SDC database all merger, divestiture, and spinoff transactions for the respective firm-years. Diversifying merger events are then defined as firm-years in which a company reports an increase in segments by at least one in Compustat's Segement database and also undertakes at least one diversifying merger (i.e., a merger with a target firm with different SIC code) according to SDC.

We use the standard market model approach to estimate abnormal stock returns and define the day of the merger announcement as indicated in SDC as the event day $(t=0)$. The 
parameters from the market model are estimated over a 252-day estimation period ending 46 days before the event day using the equally weighted CRSP market index. Cumulative abnormal returns (CARs) are calculated over a 22-day period from $t=-20$ to $t=+1$. If a firm undertakes more than one merger in the same year, we calculate a 22-day CAR for each merger event and build the sum of the respective CARs within that year. ${ }^{16}$ In total we identify 1,419 sample-years (out of more than 37,000) with at least one diversifying acquisition. The CARs surrounding these acquisitions have a mean of $+1.0 \%$ and median of $0.7 \%$ with borderline statistical significance.

To investigate the interaction between the quality of corporate governance and the value effects of diversification, we regress the CARs from the event study on our corporate governance attributes as well as our principal component governance indices. We are able to include 222 acquisitions in our regression, since many sample firms do not have corporate governance variables available on the databases that we use. Results of the regression analysis appear in Table 8. The estimates show that the announcement effect associated with a diversifying acquisition is significantly lower if the firm is already diversified. Most importantly, five out of eight coefficients on the corporate governance attributes are estimated significantly, all of them suggesting that better corporate governance leads to less value destruction (or more value creation) through diversifying mergers. Specifically, we find more positive announcement effects when institutional ownership is high, board size is low, more independent outside directors sit on the board, the nominating committee is completely independent, and the board is not classified.

In the right column we replace the individual governance attributes by the three principal component governance indices. The positive and significant coefficients on the second and third indices again indicate that better corporate governance is associated with higher announcement effects.

\footnotetext{
${ }^{16}$ The results remain qualitatively similar when we build the average instead of the sum over the CARs of one specific firm within one year.
} 


\section{Conclusions}

Two important sources of company value are governance and diversification. In this paper we investigate links between these two issues, seeking to determine whether the agency problems inherent in poor corporate governance drive firms to diversify, thereby eroding corporate value through the diversification discount.

Once we account for the impact of corporate governance on firm value, we estimate lower magnitudes of the diversification discount. However, in all our models the discount is estimated as negative and significant, indicating that it is not simply a proxy for poor corporate governance. Our results suggest that the valuation-effect of corporate diversification depends significantly upon governance factors. For example, firms in which the CEO holds a higher percentage of shares and firms with more independent directors on the board are less likely to implement value-destroying diversification strategies.

Our results are robust to techniques used to account for both the endogeneity of the corporate diversification decision as well as the endogeneity of the corporate governance attributes. An event study of diversifying mergers by our sample firms reinforces the findings from the panel data regressions, namely that better corporate governance is associated with less value destruction (or more value creation) as measured by shareholder reactions to the mergers. 


\section{References}

Adams, R.B., H. Almeida, and D. Ferreira, 2005, Powerful CEOs and their impact on corporate performance, Review of Financial Studies 18, 1403-1432.

Aggarwal, R.K., and A.A. Samwick, 2003, Why do managers diversify their firms? Agency reconsidered, Journal of Finance 58, 71-118.

Agrawal, A., and C.R. Knoeber, 1996, Firm performance and mechanisms to control agency problems between managers and shareholders, Journal of Financial and Quantitative Analysis 31, 377-397.

Amihud, Y., and B. Lev, 1981, Risk reduction as a managerial motive for conglomerate mergers, Bell Journal of Economics 12, 605-617.

Ammann, M., D. Hoechle, and M.M. Schmid, 2009, Is there really no conglomerate discount? Unpublished manuscript, University of St. Gallen.

Anderson, R.C., T.W. Bates, J.M. Bizjak, and M.L. Lemmon, 2000, Corporate governance and firm diversification, Financial Management 78, 5-22.

Arellano, M., and O. Bover, 1995, Another look at the instrumental variable estimation of error-component models, Journal of Econometrics 68, 29-51.

Baker, G.P., 1992, Beatrice: A study in the creation and destruction of value, Journal of Finance 47, 1081-1119.

Berger, P., and E. Ofek, 1995, Diversification's effect on firm value, Journal of Financial Economics 37, 39-65.

Blundell, R., and S. Bond, 1998, Initial conditions and moment restrictions in dynamic panel data models, Journal of Econometrics 87, 115-143.

Brick, I.E., and N.K. Chidambaran, 2007, Board meetings, committee structure, and firm performance, Unpublished manuscript, Rutgers University.

Bushman, R., E. Engel, and A. Smith, 2004, Financial accounting information, organizational complexity and corporate governance systems, Journal of Accounting and Economics 37, 167-201.

Campa, J.M., and S. Kedia, 2002, Explaining the diversification discount, Journal of Finance 57, 1731-1762.

Coles, J.L., N. Daniel, and L. Naveen, 2008, Boards: Does one size fit all? Journal of Financial Economics 87, 329-356.

Coles, J., M. Lemmon, and F. Meschke, 2006, Structural models and endogeneity in corporate finance: The link between managerial ownership and corporate performance, Unpublished manuscript, Arizona State University. 
Denis, D.J., D.K. Denis, and A. Sarin, 1997, Agency problems, equity ownership, and corporate diversification, Journal of Finance 52, 135-160.

Driscoll, J.C., and A.C. Kraay, 1998, Consistent covariance matrix estimation with spatially dependent panel data, Review of Economics and Statistics 80, 549-560.

Dlugosz, J., R. Fahlenbrach, P. Gompers, and A. Metrick, 2006, Large blocks of stock: Prevalence, size, and measurement, Journal of Corporate Finance 12, 594-618.

Faleye, O., 2007, Classified boards, firm value, and managerial entrenchment, Journal of Financial Economics 83, 501-529.

Fauver, L., J. Houston, and A. Naranjo, 2003, Capital market development, international integration, legal systems, and the value of corporate diversification: A cross-country analysis, Journal of Financial and Quantitative Analysis 38, 135-157.

Glaser, M., and S. Mueller, 2009, Is the diversification discount caused by the book value bias of debt? Unpublished manuscript, University of Mannheim.

Gompers, P.A., J.L. Ishii, and A. Metrick, 2003, Corporate Governance and Equity Prices, Quarterly Journal of Economics 118, 107-155.

Graham, J., M. Lemmon, and J. Wolf, 2002, Does corporate diversification destroy value? Journal of Finance 57, 695-720.

Grass, G., 2009, The impact of corporate diversification on the option value of equity, Unpublished manuscript, European Business School.

Habib, M.A., and A. Ljungqvist, 2005, Firm value and managerial incentives: A stochastic frontier approach, Journal of Business 78, 2053-2093.

Hermalin, B.E., and M.S. Weisbach, 2004, Boards of directors as an endogenously determined institution: A survey of the economic literature, Federal Reserve Bank of New York (FRBNY) Economic Policy Review 9, 7-26.

Houston, J.F., C.M. James, and M.D. Ryngaert, 2001, Where do merger gains come from? Bank mergers from the perspective of insiders and outsiders, Journal of Financial Economics 60, 285-331.

Kole, S.R., 1995, Measuring managerial equity ownership: A comparison of sources of ownership data, Journal of Corporate Finance 1, 413-435.

Laeven, L., and R. Levine, 2007, Is there a diversification discount in financial conglomerates? Journal of Financial Economics 85, 331-367.

Lamont, O., 1997, Cash flow and investment: Evidence from internal capital markets, Journal of Finance 52, 83-109.

Lang, L. H. P., and R. M. Stulz, 1994, Tobin's Q, corporate diversification, and firm performance, Journal of Political Economy 102, 1248-1280. 
Larcker, D., S. Richardson, and I. Tuna, 2007, Corporate governance, accounting outcomes and organizational performance, The Accounting Review 82, 963-1008.

Lins, K., and H. Servaes, 1999, International evidence on the value of corporate diversification, Journal of Finance 54, 2215-2239.

Lins, K., and H. Servaes, 2002, Is corporate diversification beneficial in emerging markets? Financial Management 31, 5-31.

Mansi, S.A., and D.M. Reeb, 2002, Corporate diversification: What gets discounted? Journal of Finance 57, 2167-2183.

McConnell, J., and H. Servaes, 1990, Additional evidence on equity ownership and corporate value, Journal of Financial Economics 27, 595-613.

Merton, R.C., 1974, On the pricing of corporate debt: The risk structure of interest rates, Journal of Finance 29, 449-470.

Ozbas, O., and D. S. Scharfstein, 2008, Evidence on the dark side of internal capital markets, Review of Financial Studies, forthcoming.

Schmid, M.M., and I. Walter, 2009, Do financial conglomerates create or destroy economic value?, Journal of Financial Intermediation 18, 193-216.

Villalonga, B., 2004a, Does diversification cause the diversification discount?, Financial Management 33, 5-27.

Villalonga, B., 2004b, Diversification discount or premium? New evidence from the Business Information Tracking Series, Journal of Finance 59, 479-506.

Wintoki, M.B., J.S. Linck, and J.M. Netter, 2008, Endogeneity and the dynamics of corporate governance, Unpublished manuscript, University of Kansas School of Business.

Yermack, D., 1996, Higher market valuation of companies with a small board of directors, Journal of Financial Economics 40, 185-211. 
Table 1

\section{Descriptive statistics - comparison of focused and diversified firms}

The table presents mean and median values of financial and corporate governance variables for subsamles of focused and diversified companies. All firms with more than one business segment are classified as diversified. The "powerful" CEO dummy variable equals 1 when the CEO is the only insider on the board and also serves as chairman and president. The governance index is based upon Gompers, Ishii, and Metrick (2003) and includes 24 provisions related to takeover defenses and shareholder rights. The equality of means is tested using a $t$-test, and the equality of medians test uses a Wilcoxon signed rank statistic.

Excess value (sales)

Excess value (assets)

Excess value (hybrid)

Tobin's Q

Sample means

Sample medians

Observations

$\begin{array}{rrrrrrr}\text { Focused } & \text { Diversified Difference } & \text { Focused } & \text { Diversified Difference } & \\ -0.056 & -0.115 & 0.058 * * * & 0.000 & -0.110 & 0.110 * * * & 37,740 \\ -0.022 & -0.089 & 0.068 * * * & 0.000 & -0.093 & 0.093 * * * & 34,557 \\ -0.048 & -0.093 & 0.045 * * * & 0.000 & -0.092 & 0.092 * * * & 37,740 \\ 1.854 & 1.608 & 0.246 * * * & 1.457 & 1.371 & 0.086 * * * & 37,663 \\ & & & & & & \\ \$ 1,041 & \$ 2,515 & (\$ 1,474) * * * & \$ 139 & \$ 322 & (\$ 183) * * * & 37,740 \\ \$ 845 & \$ 1,929 & (\$ 1,084) * * * & \$ 167 & \$ 428 & (\$ 261)^{* * *} & 37,740 \\ \$ 855 & \$ 2,229 & (\$ 1,374) * * * & \$ 156 & \$ 428 & (\$ 272) * * * & 37,740 \\ 0.562 & 0.594 & -0.031 * * * & 0.525 & 0.576 & -0.051 * * * & 37,730 \\ 0.032 & 0.064 & -0.032 * * * & 0.063 & 0.074 & -0.011 * * * & 37,683 \\ 0.105 & 0.075 & 0.030 * * * & 0.040 & 0.040 & 0.000 & 37,319 \\ 0.087 & 0.039 & 0.048 * * * & 0.026 & 0.017 & 0.009 * * * & 20,876 \\ 0.405 & 0.321 & 0.085 * * * & 0.212 & 0.163 & 0.049 * * * & 32,354 \\ & & & & & & \\ 0.056 & 0.050 & 0.006 * * & 0.019 & 0.014 & 0.005 * * * & 6,655 \\ 0.411 & 0.474 & -0.064 * * * & 0.377 & 0.494 & -0.117 * * * & 22,873 \\ 0.192 & 0.173 & 0.019 * * * & 0.173 & 0.141 & 0.032 * * * & 2,769 \\ 8.255 & 9.260 & -1.005 * * * & 8.000 & 9.000 & -1.000 * * * & 6,181 \\ 0.611 & 0.662 & -0.051 * * * & 0.625 & 0.692 & -0.067 * * * & 6,181 \\ 0.751 & 0.730 & 0.021 * & 1.000 & 1.000 & 0.000 * & 6,181 \\ 0.313 & 0.365 & -0.052 * * * & 0.222 & 0.300 & -0.078 * * * & 2,805 \\ 0.077 & 0.126 & -0.049 * * * & 0.000 & 0.000 & -0.000 * * * & 6,181 \\ 8.698 & 9.642 & -0.945 * * * & 9.000 & 10.000 & -1.000 * * * & 8,064 \\ 0.577 & 0.647 & -0.071 * * * & 1.000 & 1.000 & -0.000 * * * & 8,064\end{array}$

Market value of equity (millions)

Sales (millions)

Total assets (millions)

Leverage (total debt / total assets)

$\mathrm{EBIT} /$ sales

Capital expenditures / sales

Research \& development / sales

Sales growth (prior three years)

CEO ownership

Institutional investor ownership

Outside blockholder ownership

Board size

$\%$ of independent outside directors

Indep. nominating committee dummy variable

$\%$ of directors whose tenure predates CEO

"Powerful" CEO dummy variable

Governance Index

Classified board dummy variable

Significant at $1 \%(* * *), 5 \%(* *)$ and 10\% (*) levels. 


\section{Table 2}

Fixed effects regressions of excess value on diversification for different sample periods

The table reports fixed effects regression estimates of the diversification discount. The dependent variables are excess firm value measures based upon sales, assets, and both (hybrid), as shown in the first three rows of Table 1. The main independent variable is a dummy variable for whether the firm is diversified. Regressions also include a range of other control variables. Columns 1-3 report results for the full sample period (1992-2005), columns 4-6 for the 19921997 period (before the reporting change from SFAS 14 to SFAS 131), and columns 7-9 for the 1998-2005 period (after the reporting change). All

regressions include year and firm fixed effects. $t$-statistics in parentheses are based on Driscoll and Kraay (1998) standard errors which are heteroskedasticconsistent and robust to general forms of cross-sectional and temporal dependence.

\begin{tabular}{|c|c|c|c|c|c|c|c|c|c|}
\hline Sample period: & & 1992-2005 & & & 1992-1997 & & & 1998-2005 & \\
\hline Excess value measure: & Sales & Assets & Hybrid & Sales & Assets & Hybrid & Sales & Assets & Hybrid \\
\hline Intercept & $\begin{array}{l}-0.284 \text { *** } \\
(2.73)\end{array}$ & $\begin{array}{l}0.401 \text { *** } \\
(6.68)\end{array}$ & $\begin{array}{c}-0.143 * \\
(1.95)\end{array}$ & $\begin{array}{r}-0.192 \\
(1.28)\end{array}$ & $\begin{array}{l}0.582 * * * \\
(9.15)\end{array}$ & $\begin{array}{r}-0.004 \\
(0.04)\end{array}$ & $\begin{array}{l}-0.616^{* * *} \\
(4.85)\end{array}$ & $\begin{array}{l}0.606 \text { *** } \\
(7.33)\end{array}$ & $\begin{array}{l}-0.173^{* * *} \\
(3.65)\end{array}$ \\
\hline $\begin{array}{l}\text { Diversification } \\
\text { Dummy variable }\end{array}$ & $\begin{array}{l}-0.113 * * * \\
(12.41)\end{array}$ & $\begin{array}{l}-0.074 * * * \\
(6.42)\end{array}$ & $\begin{array}{l}-0.086 * * * \\
(8.08)\end{array}$ & $\begin{array}{l}-0.108 * * * \\
(7.87)\end{array}$ & $\begin{array}{l}-0.058 * * * \\
(3.41)\end{array}$ & $\begin{array}{l}-0.077 * * * \\
(5.21)\end{array}$ & $\begin{array}{l}-0.127 * * * \\
(6.90)\end{array}$ & $\begin{array}{l}-0.081 * * * \\
(5.92)\end{array}$ & $\begin{array}{l}-0.110 * * * \\
(6.59)\end{array}$ \\
\hline $\begin{array}{l}\text { Firm size } \\
\text { (log of total assets) }\end{array}$ & $\begin{array}{l}0.030 * \\
(1.66)\end{array}$ & $\begin{array}{l}-0.075 * * * \\
(7.43)\end{array}$ & $\begin{array}{l}0.009 \\
(0.67)\end{array}$ & $\begin{array}{l}0.029 \\
(1.09)\end{array}$ & $\begin{array}{l}-0.120 * * * \\
(8.47)\end{array}$ & $\begin{array}{r}-0.005 \\
(0.30)\end{array}$ & $\begin{array}{l}0.087 * * * \\
(3.75)\end{array}$ & $\begin{array}{l}-0.110 * * * \\
(9.27)\end{array}$ & $\begin{array}{l}0.016 \\
(1.55)\end{array}$ \\
\hline $\begin{array}{l}\text { Capital expenditures } \\
\text { / sales }\end{array}$ & $\begin{array}{l}0.479 * * * \\
(9.51)\end{array}$ & $\begin{array}{l}0.136 * * * \\
(5.93)\end{array}$ & $\begin{array}{l}0.236 * * * \\
(6.06)\end{array}$ & $\begin{array}{l}0.329 * * * \\
(8.54)\end{array}$ & $\begin{array}{l}0.085 * * * \\
(5.26)\end{array}$ & $\begin{array}{l}0.140 * * * \\
(4.36)\end{array}$ & $\begin{array}{l}0.444 * * * \\
(7.15)\end{array}$ & $\begin{array}{l}0.172 * * * \\
(12.00)\end{array}$ & $\begin{array}{l}0.245 * * * \\
(4.09)\end{array}$ \\
\hline $\begin{array}{l}\text { EBIT } \\
\text { / sales }\end{array}$ & $\begin{array}{l}0.265 \text { *** } \\
(3.55)\end{array}$ & $\begin{array}{l}0.300 * * * \\
(5.40)\end{array}$ & $\begin{array}{l}0.345^{* * *} \\
(3.73)\end{array}$ & $\begin{array}{l}0.551 \text { *** } \\
(17.24)\end{array}$ & $\begin{array}{l}0.758 \text { *** } \\
(17.52)\end{array}$ & $\begin{array}{l}0.644^{* * *} \\
(16.33)\end{array}$ & $\begin{array}{l}0.125 \text { *** } \\
(3.37)\end{array}$ & $\begin{array}{l}0.190 * * * \\
(8.05)\end{array}$ & $\begin{array}{l}0.198 \text { *** } \\
(3.98)\end{array}$ \\
\hline $\begin{array}{l}\text { Sales growth } \\
\text { (prior three years) }\end{array}$ & $\begin{array}{l}0.028 * * * \\
(5.10)\end{array}$ & $\begin{array}{l}0.022 * * * \\
(3.62)\end{array}$ & $\begin{array}{l}0.032 * * * \\
(5.20)\end{array}$ & $\begin{array}{l}0.007 \\
(0.93)\end{array}$ & $\begin{array}{l}0.033 * * \\
(2.15)\end{array}$ & $\begin{array}{l}0.015 * \\
(1.83)\end{array}$ & $\begin{array}{l}0.019 * * * \\
(3.35)\end{array}$ & $\begin{array}{l}0.014 * * \\
(2.46)\end{array}$ & $\begin{array}{l}0.026 * * * \\
(10.65)\end{array}$ \\
\hline Leverage & $\begin{array}{r}-0.023 \\
(1.11)\end{array}$ & $\begin{array}{l}-0.116 * * * \\
(5.09)\end{array}$ & $\begin{array}{r}-0.021 \\
(1.28)\end{array}$ & $\begin{array}{l}-0.164 * * * \\
(21.09)\end{array}$ & $\begin{array}{l}-0.111 * * * \\
(10.41)\end{array}$ & $\begin{array}{l}-0.157 * * * \\
(15.83)\end{array}$ & $\begin{array}{l}0.003 \\
(0.37)\end{array}$ & $\begin{array}{l}-0.078 * * \\
(2.28)\end{array}$ & $\begin{array}{r}-0.003 \\
(0.70)\end{array}$ \\
\hline R-squared (within) & 0.063 & 0.048 & 0.041 & 0.073 & 0.077 & 0.050 & 0.058 & 0.036 & 0.033 \\
\hline Number of firms & 6,180 & 5,930 & 6,180 & 4,346 & 4,065 & 4,346 & 4,546 & 4,194 & 4,546 \\
\hline Observations & 31,946 & 28,904 & 31,946 & 15,567 & 13,763 & 15,567 & 16,379 & 15,141 & 16,379 \\
\hline
\end{tabular}

Significant at $1 \%(* * *), 5 \%(* *)$ and $10 \%(*)$ levels. 


\section{Table 3}

Fixed effects regressions of excess value on diversification and governance variables The table reports fixed effects regression estimates of the diversification discount. The dependent variable is an excess value firm measure based on sales, as shown in the first row of Table 1. The main independent variable is a dummy variable for whether the firm is diversified. In columns 2,4 , and 6 , the basic regressions are augmented by a range of corporate governance variables. In addition, all regressions include the following control variables: $\ln$ (assets), CAPX/sales, EBIT/sales, sales growth, and leverage, as well as year and firm fixed effects. In columns 3 and 4 , the firm fixed effects are allowed to vary between years with positive and negative stock market (S\&P 500) returns, and in columns 5 and 6 they vary between boom and recession periods as measured by a dummy variable for GDP growth above or below median growth. $t$-statistics in parentheses are based on Driscoll and Kraay (1998) standard errors which are heteroskedastic-consistent and robust to general forms of cross-sectional and temporal dependence.

\begin{tabular}{|c|c|c|c|c|c|c|}
\hline \multirow[b]{2}{*}{ Intercept } & \multicolumn{2}{|c|}{ Standard Fixed Effects } & \multicolumn{2}{|c|}{$\begin{array}{c}\text { Fixed Effects } \\
\text { (Stock Market Return) }\end{array}$} & \multicolumn{2}{|c|}{$\begin{array}{l}\text { Fixed Effects } \\
\text { (GDP Growth) }\end{array}$} \\
\hline & $\begin{array}{l}-0.490 \\
(-1.32)\end{array}$ & $\begin{array}{l}-1.225 * * * \\
(-3.03)\end{array}$ & $\begin{array}{c}-0.374 \\
(1.29)\end{array}$ & $\begin{array}{l}-1.334 * * * \\
(3.32)\end{array}$ & $\begin{array}{r}-0.251 \\
(0.84)\end{array}$ & $\begin{array}{l}-0.889 * * * \\
(3.19)\end{array}$ \\
\hline Diversification dummy variable & $\begin{array}{l}-0.093 * * * \\
(3.06)\end{array}$ & $\begin{array}{l}-0.081 * * * \\
(3.20)\end{array}$ & $\begin{array}{l}-0.081 * * * \\
(2.78)\end{array}$ & $\begin{array}{l}-0.069 * \\
(1.73)\end{array}$ & $\begin{array}{l}-0.063^{* * * *} \\
(2.62)\end{array}$ & $\begin{array}{l}-0.051 * \\
(1.75)\end{array}$ \\
\hline CEO ownership & & $\begin{array}{l}0.014 \text { *** } \\
(4.45)\end{array}$ & & $\begin{array}{l}0.018^{* * *} \\
(7.55)\end{array}$ & & $\begin{array}{l}0.011 \text { *** } \\
(2.91)\end{array}$ \\
\hline CEO ownership squared & & $\begin{array}{l}-0.000 * * \\
(2.44)\end{array}$ & & $\begin{array}{l}-0.000 \text { *** } \\
(4.35)\end{array}$ & & $\begin{array}{l}-0.000 * \\
(1.66)\end{array}$ \\
\hline Institutional ownership & & $\begin{array}{l}0.715^{* * *} \\
(7.96)\end{array}$ & & $\begin{array}{l}0.874 \text { *** } \\
(9.77)\end{array}$ & & $\begin{array}{l}0.666 * * * \\
(5.83)\end{array}$ \\
\hline Log (Board size) & & $\begin{array}{l}-0.051 * \\
(1.76)\end{array}$ & & $\begin{array}{r}-0.045 \\
(1.54)\end{array}$ & & $\begin{array}{l}-0.052 * \\
(1.79)\end{array}$ \\
\hline Board independence (\%) & & $\begin{array}{r}-0.028 \\
(0.97)\end{array}$ & & $\begin{array}{r}-0.094 \\
(1.50)\end{array}$ & & $\begin{array}{l}-0.093 * \\
(1.65)\end{array}$ \\
\hline $\begin{array}{l}\text { Independent nominating committee } \\
\text { dummy variable }\end{array}$ & & $\begin{array}{l}-0.028 * \\
(1.84)\end{array}$ & & $\begin{array}{l}-0.018 \\
(1.16)\end{array}$ & & $\begin{array}{r}-0.016 \\
(0.91)\end{array}$ \\
\hline "Powerful” CEO dummy variable & & $\begin{array}{l}-0.026 \\
(0.74)\end{array}$ & & $\begin{array}{r}0.017 \\
(0.44)\end{array}$ & & $\begin{array}{l}-0.045 \\
(1.45)\end{array}$ \\
\hline Governance index & & $\begin{array}{l}-0.001 \\
(0.25)\end{array}$ & & $\begin{array}{c}0.010 \\
(1.37)\end{array}$ & & $\begin{array}{r}-0.001 \\
(0.45)\end{array}$ \\
\hline Classified board dummv variable & & $\begin{array}{l}-0.038 * \\
(1.71)\end{array}$ & & $\begin{array}{r}-0.019 \\
(0.71)\end{array}$ & & $\begin{array}{l}-0.047 \\
(0.93)\end{array}$ \\
\hline R-squared (within) & 0.069 & 0.116 & 0.061 & 0.122 & 0.040 & 0.122 \\
\hline Number of firms & 711 & 711 & 711 & 711 & 711 & 711 \\
\hline Observations & 2,427 & 2,427 & 2,427 & 2,427 & 2,427 & 2,427 \\
\hline
\end{tabular}

Significant at $1 \%(* * *), 5 \%(* *)$ and $10 \%(*)$ levels. 
Table 4

Fixed effects regressions of excess value on governance variables and interaction terms

The table reports fixed effects regression estimates of the diversification discount. The dependent variable is an excess firm value measure based on sales, as shown in the first row of Table 1 . The main independent variable is a dummy variable for whether the firm is diversified. The left column reproduces the results from the second column of Table 3. The right column shows estimates for a model augmented by interaction terms between the governance variables and the dummy variable for diversification. All regressions include the following control variables: $\ln$ (assets), CAPX/sales, EBIT/sales, sales growth, and leverage, as well as year and firm fixed effects. $t$-statistics in parentheses are based on Driscoll and Kraay (1998) standard errors which are heteroskedastic-consistent and robust to general forms of cross-sectional and temporal dependence.

Intercept

Diversification dummy variable

CEO ownership

CEO ownership squared

Institutional ownership

Log (Board size)

Board independence (\%)

Independent nominating committee dummy variable

“Powerful” CEO dummy variable

Governance index

Classified board dummy variable

CEO ownership x diversification dummy variable

Institutional ownership x diversification dummy variable

Log (Board size) x diversification dummy variable

Board independence (\%) x diversification dummy variable

Independent nominating committee $\mathrm{x}$ diversification dummy variable

“Powerful” CEO dummy variable x diversification dummy variable

Governance index x diversification dummy variable

Classified board dummy variable $\mathrm{x}$ diversification dummy variable

R-squared (within)

Observations
Number of firms

\begin{tabular}{|c|c|}
\hline$-1.225 * * *$ & $-1.034 * *$ \\
\hline (3.03) & $(2.35)$ \\
\hline$-0.081 * * *$ & $-0.761 * * *$ \\
\hline (3.20) & (3.03) \\
\hline $0.014^{* * *}$ & $0.013 * * *$ \\
\hline$(4.45)$ & $(4.21)$ \\
\hline$-0.000 * *$ & $-0.000 * *$ \\
\hline$(2.44)$ & $(2.48)$ \\
\hline $0.715 * * *$ & $0.673 * * *$ \\
\hline (7.96) & $(6.54)$ \\
\hline$-0.051 *$ & $-0.042 *$ \\
\hline$(1.76)$ & $(1.77)$ \\
\hline-0.028 & $-0.058 * * *$ \\
\hline$(0.97)$ & $(4.64)$ \\
\hline$-0.028 *$ & -0.017 \\
\hline (1.84) & $(0.43)$ \\
\hline-0.026 & -0.009 \\
\hline (0.74) & $(0.46)$ \\
\hline-0.001 & $-0.021 * * *$ \\
\hline$(0.25)$ & $(4.03)$ \\
\hline$-0.038 *$ & 0.041 \\
\hline$(1.71)$ & $(1.40)$ \\
\hline & $0.006 * *$ \\
\hline & $(2.22)$ \\
\hline & 0.175 \\
\hline & (1.15) \\
\hline & $0.158 *$ \\
\hline & $(1.91)$ \\
\hline & $0.077 * *$ \\
\hline & $(2.48)$ \\
\hline & -0.026 \\
\hline & $(0.66)$ \\
\hline & -0.029 \\
\hline & $(0.34)$ \\
\hline & $0.043 * * *$ \\
\hline & $(7.31)$ \\
\hline & $-0.278 * * *$ \\
\hline & $(4.50)$ \\
\hline 0.116 & 0.128 \\
\hline 711 & 711 \\
\hline 2,427 & 2,427 \\
\hline
\end{tabular}

Significant at $1 \%(* * *), 5 \%(* *)$ and $10 \%\left(^{*}\right)$ levels. 


\section{Table 5}

\section{Corporate governance indices based on principal component analysis}

The table presents detail about the principal component analysis used to combine information about eight corporate governance variables into three indices. The computations follow Larcker, Richardson, and Tuna (2007), using equal weighted averages of standardized versions of those governance variables with factor loadings in excess of 0.40 in absolute terms. Panel A reports the factor loadings for the first three principal components. Figures in bold print indicate factor loadings in excess of 0.40 in absolute terms. Panel B reports the names assigned to each principal component based on the governance variables which exhibit factor loadings in excess of 0.40 in absolute value, and it also reports the expected sign of the association between each component and firm value. The bottom two rows of Panel B show the percentage of total variance in the governance variables explained by each principal component separately and cumulatively. The principal component analysis is based on the 2,427 observations on 711 firms for which all eight governance variables are available.

Details about the definitions and sources of each governance variable appear in the text.

\section{Panel A: Factor loading}

CEO ownership
Institutional investor ownership
Board size
\% of independent outside directors
Indep. nominating cmte. dummy variable
"Powerful" CEO dummy variable
Governance index
Classified board dummy variable

\section{Panel B: Description}

Expected association with firm value

Variance explained

Variance explained (cumulative)
Principal

Component 1

$-0.0258$

$-0.1333$

0.3385

0.2182

0.0547

0.1270

0.6347

0.6304

Takeover

provisions

and board

characteristics

0.2155

0.2155
Principal

Component 2

$$
\begin{array}{r}
\mathbf{- 0 . 6 0 3 5} \\
\mathbf{0 . 6 2 4 3} \\
-0.0864 \\
\mathbf{0 . 4 6 4 9} \\
-0.0467 \\
0.0954 \\
0.0626 \\
-0.0854
\end{array}
$$

Principal

Component 3
0.1944
0.0070
$\mathbf{- 0 . 4 3 6 2}$
0.2851
0.8185
$-0.0685$
$-0.0341$
0.1221

$\begin{array}{rr}\text { Ownership } & \\ \text { structure } & \\ \text { and outside } & \text { Board } \\ \text { directors } & \text { characteristics } \\ + & + \\ 0.2044 & 0.1448 \\ 0.4198 & 0.5646\end{array}$




\section{Table 6}

\section{Fixed effects regressions of excess value on governance variables}

The table reports fixed effects regression estimates of the diversification discount. The dependent variable is an excess firm value measure based on sales, as shown in the first row of Table 1. The main independent variable is a dummy variable for whether the firm is diversified. In columns 2,4 , and 6 , the basic regressions are augmented by corporate governance indices which are based on principal component analysis, as shown in Table 5. All regressions include the following control variables: $\ln$ (assets), CAPX/sales, EBIT/sales, sales growth, and leverage, as well as year and firm fixed effects. In columns 3 and 4, the firm fixed effects are allowed to vary between years with positive and negative stock market (S\&P 500) returns, and in columns 5 and 6 they vary between boom and recession periods as measured by a dummy variable for GDP growth above or below median growth. $t$-statistics in parentheses are based on Driscoll and Kraay (1998) standard errors which are heteroskedastic-consistent and robust to general forms of cross-sectional and temporal dependence.

\begin{tabular}{|c|c|c|c|c|c|c|}
\hline \multirow[b]{2}{*}{ Intercept } & \multicolumn{2}{|c|}{ Standard Fixed Effects } & \multicolumn{2}{|c|}{$\begin{array}{c}\text { Fixed Effects } \\
\text { (Stock Market Return) }\end{array}$} & \multicolumn{2}{|c|}{$\begin{array}{l}\text { Fixed Effects } \\
\text { (GDP Growth) }\end{array}$} \\
\hline & $\begin{array}{l}-0.490 \\
(-1.32)\end{array}$ & $\begin{array}{l}-0.739 * \\
(1.68)\end{array}$ & $\begin{array}{l}-0.374 \\
(1.29)\end{array}$ & $\begin{array}{r}-0.632 \\
(1.51)\end{array}$ & $\begin{array}{l}-0.251 \\
(0.84)\end{array}$ & $\begin{array}{r}-0.461 \\
(1.40)\end{array}$ \\
\hline Diversification dummy variable & $\begin{array}{l}-0.093^{* * *} \\
(3.06)\end{array}$ & $\begin{array}{l}-0.067 * * * \\
(2.72)\end{array}$ & $\begin{array}{l}-0.081 * * * \\
(2.78)\end{array}$ & $\begin{array}{l}-0.048 * \\
(1.76)\end{array}$ & $\begin{array}{l}-0.063 * * * \\
(2.62)\end{array}$ & $\begin{array}{l}-0.038 * \\
(1.75)\end{array}$ \\
\hline Governance index 1 & & $\begin{array}{l}-0.030 * \\
(1.76)\end{array}$ & & $\begin{array}{l}0.005 \\
(0.29)\end{array}$ & & $\begin{array}{l}-0.034 * \\
(1.73)\end{array}$ \\
\hline Governance index 2 & & $\begin{array}{l}0.093 * * * \\
(4.34)\end{array}$ & & $\begin{array}{l}0.116 * * * \\
(3.93)\end{array}$ & & $\begin{array}{l}0.071 \text { *** } \\
(3.70)\end{array}$ \\
\hline Governance index 3 & & $\begin{array}{l}-0.020 * * \\
(2.35)\end{array}$ & & $\begin{array}{l}-0.019 \\
(1.52)\end{array}$ & & $\begin{array}{r}-0.015 \\
(1.58)\end{array}$ \\
\hline R-squared (within) & 0.069 & 0.074 & 0.061 & 0.069 & 0.040 & 0.057 \\
\hline Number of firms & 711 & 711 & 711 & 711 & 711 & 711 \\
\hline Observations & 2,427 & 2,427 & 2,427 & 2,427 & 2,427 & 2,427 \\
\hline
\end{tabular}

Significant at $1 \%\left({ }^{* * *}\right), 5 \%(* *)$ and $10 \%(*)$ levels. 


\section{Table 7}

\section{Dynamic panel GMM estimations of excess value on governance variables}

The table reports the results from regressions of the excess firm value measure based on sales on a dummy variable for whether the firm is diversified, excess firm value with one and two lags, and control variables. The regressions are estimated by using a dynamic panel GMM estimator as proposed by Arellano and Bover (1995) and Blundell and Bond (1998). In column 2 the basic regression is augmented by a set of nine individual governance variables and in column 3 by three corporate governance indices which are based on principal component analysis, as shown in Table 5. All regressions include the following control variables: $\ln$ (assets), CAPX/sales, EBIT/sales, sales growth, leverage, and year dummy variables. All control variables are considered to be endogenous with the exception of the year dummy variables. AR(1) and AR(2) are tests for first-order and second-order serial correlation in the first differenced residuals with the null hypothesis of no serial correlation.

\begin{tabular}{|c|c|c|c|}
\hline Intercept & $\begin{array}{r}-0.131 \\
(-0.628)\end{array}$ & $\begin{array}{l}-0.731 \text { *** } \\
(-3.342)\end{array}$ & $\begin{array}{l}-0.473 * * \\
(-2.536)\end{array}$ \\
\hline Diversification & $\begin{array}{l}-0.113^{* *} \\
(-2.384)\end{array}$ & $\begin{array}{l}-0.080 * \\
(-1.686)\end{array}$ & $\begin{array}{r}-0.070 \\
(-1.314)\end{array}$ \\
\hline Excess Value (1 lag) & $\begin{array}{l}0.439 * * * \\
(13.959)\end{array}$ & $\begin{array}{l}0.429 * * * \\
(14.110)\end{array}$ & $\begin{array}{l}0.425 * * * \\
(13.137)\end{array}$ \\
\hline Excess Value (2 lags) & $\begin{array}{l}0.087 * * * \\
(3.640)\end{array}$ & $\begin{array}{l}0.076 * * * \\
(2.857)\end{array}$ & $\begin{array}{l}0.067 * * \\
(2.358)\end{array}$ \\
\hline CEO ownership & & $\begin{array}{l}0.013 * * \\
(2.497)\end{array}$ & \\
\hline CEO ownership squared & & $\begin{array}{l}-0.000 * * \\
(2.141)\end{array}$ & \\
\hline Institutional ownership & & $\begin{array}{l}0.654 \text { *** } \\
(6.568)\end{array}$ & \\
\hline Log (Board size) & & $\begin{array}{l}-0.069 * \\
(-1.707)\end{array}$ & \\
\hline Board independence (\%) & & $\begin{array}{r}-0.019 \\
(-0.182)\end{array}$ & \\
\hline Independent nominating & & $\begin{array}{r}0.015 \\
(0506)\end{array}$ & \\
\hline $\begin{array}{l}\text { committee dummy variable } \\
\text { "Powerful" CEO dummy }\end{array}$ & & $\begin{array}{r}(0.506) \\
0.013\end{array}$ & \\
\hline variable & & $(0.246)$ & \\
\hline Governance index & & $\begin{array}{r}0.004 \\
(0.394)\end{array}$ & \\
\hline $\begin{array}{l}\text { Classified board dummy } \\
\text { variable }\end{array}$ & & $\begin{array}{r}0.051 \\
(0.916)\end{array}$ & \\
\hline Gov. Index 1 & & & $\begin{array}{r}0.001 \\
(0.017)\end{array}$ \\
\hline Gov. Index 2 & & & $\begin{array}{l}0.102 * * * \\
(2.815)\end{array}$ \\
\hline Gov. Index 3 & & & $\begin{array}{r}0.031 \\
(1.320)\end{array}$ \\
\hline $\mathrm{p}$-value of AR(1) test & 0.000 & 0.000 & 0.000 \\
\hline p-value of AR(2) test & 0.680 & 0.558 & 0.451 \\
\hline Number of firms & 709 & 709 & 709 \\
\hline Observations & 2,410 & 2,410 & 2,410 \\
\hline
\end{tabular}

Significant at $1 \%(* * *), 5 \%(* *)$ and $10 \%(*)$ level 


\section{Table 8}

\section{Event study results}

The table reports estimates from fixed effects regressions in which the dependent variable equals the 22-day cumulative abnormal return (CAR) around a diversifying acquisition made by a sample firm. Control variables include a dummy variable for whether the firm is diversified and a range of corporate governance variables. In the right column, the individual governance provisions are replaced by corporate governance indices based on principal component analysis, as shown in Table 5. All regressions include the following untabulated control variables: In(assets), CAPX/sales, EBIT/sales, sales growth, and leverage, as well as year and firm fixed effects. $t$-statistics in parentheses are based on Driscoll and Kraay (1998) standard errors which are heteroskedastic-consistent and robust to general forms of cross-sectional and temporal dependence.

Dependent Variable:

Constant

Diversified

CEO ownership

Institutional ownership

Log (Board size)

Board independence (\%)

Independent nominating committee dummy variable

“Powerful” CEO dummy variable

Governance index

Classified board dummy variable

Governance index 1

Governance index 2

Governance index 3

R-squared (within)

Observations

Number of Firms
Cumulative Abnormal Return $(-20,+1)$
0.497

$$
(-1.846)
$$

$-0.088 *$

$(-1.907)$

Significant at $1 \%(* * *), 5 \%(* *)$ and $10 \%\left(^{*}\right)$ levels. 